Реставрація таких складних творів потребує великого досвіду і відповідального ставлення до роботи реставратора 3 високою кваліфікаційною категорією. Реставратор без категорії повинен обов'язково працювати під керівництвом більш кваліфікованого працівника.

\title{
Література:
}

1. https://nml.com.ua/pro-muzey/korotko-pro-muzey/

2. Косів Роксолана Романівна. Українські хоругви XVII-XVIII ст.

DOI https://doi.org/10.30525/978-9934-26-004-9-68

\section{ВІЗАНТІЙСЬКО-КИЇВСЬКІ ДЖЕРЕЛА УКРАЇНСЬКОГО ІКОНОСТАСА}

\author{
Шевлюга О. А. \\ кандидат мистецтвознавства, \\ старший викладач кафедри історії і теорії мистецтва \\ Національної академії образотворчого мистецтвва і архітектури \\ м. Київ, Украӥна
}

Вівтарні перегорожі в Київській Русі були успадковані з Візантії, 3 прийняттям християнства при Київському князі Володимирі наприкінці $\mathrm{X}$ ст. 3 часом вівтарні перегорожі українських храмів трансформуються в низький іконостас під впливом відповідних змін у церквах країн візантійського ареалу. Одна із суттєвих рис у генезі українського іконостаса - тяглість іконографічних взірців, відомих у візантійськокиївському мистецтві. Серед них намісний образ Христа Пантократора на повний зріст, знаного в українському мистецтвознавстві як Христос Учитель або Милостивий: с. Вільче XV ст., с. Милик XV ст., c. Старичі XV ст., інші [5, с. 119]. В українських іконостасах такі ікони розміщувались у намісному ряді, наслідуючи візантийські приклади. Певний час побутувала думка про пізню появу в українському мистецтві цього іконографічного типу, але нам вдалось віднайти ряд пам'яток часів Київської Русі з подібною іконографією: київський хрест-енколпіон XIIXIII ст., 3 Державного історичного музею в Москві, енколпіон близько 1200 р. із Музею історії міста Києва, два срібних кратера першої чверті XII ст. із Новгородської Софії, інші [8, с. 280; 7, с. 88-89; 9, с. 64]. 
Враховуючи ту майже трагічну ситуацію зі збереженністю іконописних пам'яток часів Київської Русі та пізнішої доби XIII-XIV ст., і критично малу кількість ікон, що дійшли до нашого часу, а ікони 3 терену Київщини, Чернігівщини, Переяславщини - старих церковно-культурних центрів, до першої половини XVII ст. зовсім втрачені, то наведені домонгольські артефакти $\epsilon$ достатньо цінними свідоцтвами, що віддзеркалюють палітру художніх образів сакрального мистецтва старокиївської доби.

В колі збережених українських намісних ікон Спаса Пантократора Учителя є декілька, що мають інший нюанс цієї іконографії, а саме, до образу Христа додані дві зменшені півфігури Богородиці та Іоанна Предтечі, змальовані на рівні його голови. Подібні зміни суттєво поглиблюють богословське навантаження образу, перетворюючи його у Триморфон, деісісну композицію, із нагадуванням про Страшний Суд. Це ікони із с. Старичи XV ст., с. Лісковате кінця XV - початку XVI ст., с. Ременів кінця XV - початку XVI ст., інші [5, с. 159; 6, с. 69]. Особливу увагу викликає ікона Спаса Пантократора Деісіс XV ст. із с. Старичі, оскількі різновид іконографії цього образу не був одиноким у нашому мистецтві. Серед пам'яток часів Київської Русі вдалось відшукати аналогії цьому образу. Мова йде не тільки про зображення Христа на повний зріст, з півфігурами Богородиці й Іоанна Предтечі, але й ще одну суттєву іконографічну деталь. Збереглось два київських хрестаенколпіона 3 подібним українським іконам зображенням Пантократора Деісіс: це згадані вище хрест-енколпіон XII-XIII ст. 3 ДІМ та хрест близько 1200 р., із поховання з церкви Богородиці Пирогощої на Подолі. Ці дві вказані пам'ятки іконографічно аналогічні іконі з с. Старичі, де благословляюча рука Спаса відставлена в бік й огорнута гіматієм. Наведені аналогії виглядають не випадковими, вони свідчать про існування подібних зображень, можливо ікон, у храмах Києва та збереження й відтворення їх іконографії в інших художніх центрах української церкви.

Другий ряд іконостаса або вівтарної перегорожи в українських церквах XV-XVI ст. часто мав вигляд суцільної дошки-епістилію (c. Ванівка, с. Мшана, інші), а деісісна композиція цього також ряду грунтувалася на візантийсько-київських домонгольських іконографічних традиціях: Пентаморфон 3 різними чинами святих. Найрозповсюдженнішим варіантом центрального образа цього чина в українських іконостасах був Спас на престолі. Подібний образ у центрі Деісіса, як добре відомо, поширений у візантійському мистецтві, а серед давньоруських пам'яток наведемо київську стеатитову іконку з Деісісом і 
Борисом та Глібом XII-XIII ст. [3, с. 210]. Необхідно додати, що у центрі візантійських Деісісів зображується й іконографічний тип Христа Пантократора на повний зріст. Такий варіант Деісіса можливий i у епістиліях вівтарних перегорож, наприклад, епістилій із монастиря святої Катерини на Синаї [10, іл. 87-124]. Характерно, що збережені твори мистецтва Київської Русі демонструють такий же іконографічний ізвод Деісіса, який, вірогідно, не був надто рідкісним, а мав достатне розповсюдження в різних князівствах, наприклад: київська золота діадема 3 перегородчастою емаллю ХІІ ст., поручі Варлаама Хутинського XII ст., Деісіс на фасаді Георгіївського собора Юр'єва Польського 30-ті pp. XIII ст. та інші $[4$, с. 47-50; 9, с. 87; 1, с. 16]. Це дозволяє припускати вірогідність подібних деісісних різновидів у давньоруських та українських іконостасах. Тривалий час такі пам'ятки не були відомі українській мистецтвознавчій науці, але нещодавно, після тривалої реставрації відкрився цей давній візантійсько-київський варіант деісісного чина - ікона-епістилій першої третини XVI ст., що походить 3 Яворівщини Львівска обл. [2, с. 16]. I це не єдина українська ікона, адже у Національному музеї Львова на реставрації перебуває ще один епістилій 3 деісіснім чином із подібним іконографічним варіантом Христа на повний зріст. Наведені збережені українські намісні ікони Спаса Пантократора та деісісні чини-ряди переконують в тому, що іконографічні образи, вкорінені в домонгольському мистецтві, підтримувались і зберігались українськими художниками та священством, втілюючись надалі в українських іконостасах XV-XVI ст.

Український іконостас має ще багато елементів, образів та ідей успадкованих ним із мистецтва старокиївської доби, але існують i характерні риси, які виокремлюють його із ряду іконостасів країн візантійського ареалу й свідчать про цілісність і тяглість його розвитку, джерела якого лежать у мистецтві й культурі Київської Русі.

\section{Література:}

1. Вагнер Г. Мастера древнерусской скульптуры. М.: Искусство, 1966. $144 \mathrm{c}$.

2. Гелитович М. Українські ікони XIII - початку XVI століть зі збірки Національного музею у Львові імені Андрея Шептицького: альбом-каталог. Львів: НМЛ ім. Андрея Шептицького; Київ: Майстер Книг, 2014. 348 с.

3. Жишкович В. Образ Христа та особливості його відображення в українському малярстві XIV - XV століть. Записки Наукового 
товариства імені Шевченка / Ред. О. Купчинський. Т. 248: Праці Комісії образотворчого та ужиткового мистецтва. Львів, 2004. С. 7-36.

4. Макарова Т. И. Перегородчатые эмали Древней Руси. М.: Наука, 1975. $136 \mathrm{c}$.

5. Міляєва Л. Українська ікона XI - XVIII століть: [альбом]. К.: [б. в.], 2007. - 528 с. (Духовна спадщина України. Державні зібрання України)

6. Паріарх Дмитрій (Ярема). Іконопис Західної України XII - XV ст. Львів: Друкарські куншти, 2005. 508 с.

7. Пекарская Л. В., Пуцко В. Г. Давньоруські енколпіони в збірці музею історії м. Києва. Археологія / гол. ред. П. П. Толочко / Академія наук Української РСР / Ін-т Археології. К.: Наукова думка. Вип. 3. C. 84-94.

8. Рыбаков Б. А. Прикладное искусство Киевской Руси IX-XI веков и южнорусских княжеств XII-XIII веков. История русского искусства: в 12 т. / под общ. ред. И. Э. Грабаря. М., 1953. Т. 1. С. 233-297.

9. Рыбаков Б. А. Русское прикладное искусство Х-XIII веков [Альбом]. Ленинград: Аврора, 1970. 128 с.

10. Sotiriou G. et M. Icones du mont Sinai / G. et M. Sotiriou. Athenes, 1956.V. 2. 